M. Mariotti Lippi, A. Florenzano, R. Rinaldi, E. Allevato, D. Arobba, G. Bacchetta, M. C. Bal, M. Bandini Mazzanti, A. Benatti, J. Beneš, G. Bosi, M. Buonincontri, R. Caramiello, L. Castelletti, E. Castiglioni, A. Celant, E. Clò, L. Costantini, G. Di Pasquale, F. Di Rita, G. Fiorentino, G. Furlanetto, M. Giardini, O. Grillo, M. Guido, M. Herchenbach, D. Magri, M. Marchesini, M. Maritan, S. Marvelli, A. Masi, A. Miola, C. Montanari, M. C. Montecchi, S. Motella, R. Nisbet, M. Orrù, L. PeñaChocarro, C. Pepe, R. Perego, E. Rattighieri, C. Ravazzi, M. Rottoli, E. Rowan, D. Sabato, L. Sadori, M. Sarigu, P. Torri, M. Ucchesu \& A. M. Mercuri

\title{
The Botanical Record of Archaeobotany Italian Network - BRAIN: a cooperative network, database and website*
}

\begin{abstract}
Mariotti Lippi, M., Florenzano, A., Rinaldi, R., Allevato, E., Arobba, D., Bacchetta, G., Bal, M. C., Bandini Mazzanti, M., Benatti, A., Beneš, J., Bosi, G., Buonincontri, M., Caramiello, R., Castelletti, L., Castiglioni, E., Celant, A., Clò, E., Costantini, L., Di Pasquale, G., Di Rita, F., Fiorentino, G., Furlanetto, G., Giardini, M., Grillo, O., Guido, M., Herchenbach, M., Magri, D., Marchesini, M., Maritan, M., Marvelli, S., Masi, A., Miola, A., Montanari, C., Montecchi, M. C., Motella, S., Nisbet, R., Orrù, M., PeñaChocarro, L., Pepe, C., Perego, R., Rattighieri, E., Ravazzi, C., Rottoli, M., Rowan, E., Sabato, D., Sadori, L., Sarigu, M., Torri, P., Ucchesu M. \& Mercuri, A.M.: The Botanical Record of Archaeobotany Italian Network - BRAIN: a cooperative network, database and website. - Bocconea 28: 341-352. 2019. - ISSN: 1120-4060 printed, 2280-3882 online.

The BRAIN (Botanical Records of Archaeobotany Italian Network) database and network was developed by the cooperation of archaeobotanists working on Italian archaeological sites. Examples of recent research including pollen or other plant remains in analytical and synthetic papers are reported as an exemplar reference list. This paper retraces the main steps of the creation of BRAIN, from the scientific need for the first research cooperation to the website which has a free online access since 2015 .
\end{abstract}

Key words: archaeobotany, network, database, Italy, Mediterranean.

\footnotetext{
*Article first published online on 20 December 2018 in Flora Mediterranea 28: 365-376.
} 


\section{Introduction}

Italy is an extraordinary cradle of cultural heritage located at the centre of the Mediterranean basin, hotspot of biodiversity, rich of habitats (Blasi 2010; Bartolucci \& al. 2018) and scenery for incessant migrations and trade over the last millennia. Scholars from every side of the world come to this country to study the long-term coexistence between Culture and Nature, an interaction that has resulted in an uncountable number of archaeological sites.

Therefore, it is not a surprise that an interdisciplinary research field like archaeobotany, joining archaeology and botany, is so well developed that the study of pollen and other plant remains is more and more introduced in the archaeological projects planned in Italian sites (e.g. Roman Peasant Project: Bowes \& al. 2015; SicTransit: www.sicilyintrasition.org) or considered in the vegetation history of the Mediterranean area (e.g. Mercuri \& Sadori 2014; Fyfe \& al. 2018). The archaeobotanical approach has been especially developed for the understanding of the relationships between people and environment, genesis and developing of cultural landscapes (De Pascale \& al. 2006; Perego \& al. 2011; Di Rita \& Melis 2013; Di Rita \& al. 2018), features and spread of cultivated species (Orrù \& al. 2013; Sabato \& al. 2015, 2017; Ucchesu \& al. 2016, 2017; Bosi $\&$ al. 2017), links between plant processing and the religious value of food (Celant \& Fiorentino 2017; Primavera \& al. 2018), uses in medicinal preparations (Giachi \& al. 2013), understanding of particular practices like metallurgy (Toffolo \& al. 2018). The study of economic transformations under environmental/climate changes is investigated by considering plant exploitation and managing in prehistoric periods (de Marinis \& al. 2005; Di Rita \& al. 2010; Fiorentino \& al. 2013; Cremaschi \& al. 2016; Melis \& al. 2018; Sadori 2018) and in historical ages (Greek: Florenzano 2016; Roman: Caramiello \& al. 2013; Montecchi \& Mercuri 2018; Moser \& al. 2018; Bosi \& al. 2018; Medieval and Renaissance: Bandini Mazzanti \& al. 2005; Bosi \& al. 2009; Rottoli 2014; Buonincontri $\&$ al. 2017). The research is usually highly interdisciplinary promoting a holistic and ecological approach to knowledge (Stagno \& al. 2014; Vittori Antisari \& al. 2016; Benvenuti \& al. 2017; Arobba \& al. 2018), also connecting palaeoecology with historical perspective (Izdebski \& al. 2016), historical ecology (Moreno \& Montanari 2008; Molinari \& Montanari 2016), ecology (Marignani \& al. 2017) and conservation themes (Bosi \& al. 2015; Piovesan \& al. 2018). Land cover and land use are explored in interdisciplinary investigations carried out through the analyses of pollen, non-pollen palynomorphs, microcharcoals, seeds and fruits, woods/charcoals, and less frequently via starch grains, phytoliths and other plant parts (Revedin \& al. 2010; Guido \& al. 2013; Mariotti Lippi \& al. 2015; Pini \& al. 2016a, 2016b; Mariotti Lippi \& al. 2017). The research demonstrates that palynology is not only able to reconstruct long-term and regional vegetation history (Sadori \& al. 2013), as well as the fire history of certain regions (e.g. Lago di Como: Martinelli \& al. 2017), but this versatile science is also useful to known the 'where, when and how' of cultural landscapes development at ecological, formal and cognitive levels (Mercuri 2014). Indeed, the different approaches complement each other, highlighting the power of archaeobotany as a basic tool in reconstructing the history of past cultures and societies (Sadori \& al. 2010; Celant \& al. 2015). 


\section{From the scientific cooperation to the network}

In 2014, the $9^{\text {th }}$ EPPC European Palaeobotanical and Palynological Conference was held in Padua and saw the joint action of many Italian scholars in the fields of palaeobotany, palynology and archaeobotany. This stimulated the preparation of the book ' $\mathrm{La}$ Storia delle piante fossili in Italia/Palaeobotany of Italy' (Kustatscher \& al. 2014) which deals with the long and illustrious history of the Italian palaeobotanical studies and the classical and modern methods for analyzing plant remains. The last paper of this book (Mariotti Lippi \& al. 2014) consists of the first synthesis on the main researches (more than 200 research papers) and approaches on the botanical investigation on archaeological sites in Italy.

In this central Mediterranean country, archaeobotany was born during the first half of the $18^{\text {th }}$ century when plant remains from archaeological excavations of the Vesuvian area became the focus of interest for a number of scholars (Borgongino 2006). The well-preserved plant remains were exhibited in Palazzo Caramanico (the Royal Palace) at Portici, near Naples. Starting with the researches in Palaeolithic sites, which shed light on the diet of the hunter-gatherer populations, the paper takes into consideration the origin of agriculture, the plant resource exploitation and human impact in the Bronze Age and Iron Age, cultivation and landscape management during the Roman Period up to the Middle Ages.

As an output of that congress, moreover, a volume on 'Changing flora and vegetation in Italy through time' was edited by Bertini \& al. (2015) as special issue of the Review of Palaeobotany and Palynology hosted seventeen papers/syntheses on Permian and Triassic, Jurassic, Messinian, up to Pliocene, Pleistocene and Holocene vegetation history, probably one of the best examples of trans-chronological overview of Palaeobotany with high-level scientific examples. Three papers especially focused on archaeobotanical general (Roman harbours: Sadori \& al. 2015) and site-centered themes (Fiorentino \& Parra 2015; Mercuri $\&$ al. 2015a). Moreover, in a synthesis on the archaeobotanical research on Italian contexts (Mercuri \& al. 2015b), fifteen archaeobotanist teams working on records collected from archaeological sites put together their data to write the first paper on the 'state of the art' of the archaeobotanical research in this country.

After that joint paper, the data collected were organised in a database that is free online and ready to be improved at www.brainplants.successoterra.net (formerly https://brainplants.unimore.it/index.html).

\section{The database-network BRAIN}

BRAIN - Botanical Record of Archaeobotany Italian Network was firstly introduced at the MedPalyno2015 Congress in Rome. It is a database of archaeobotanical research and analyses from archaeological sites in Italy. Under request, this database is now integrated with sites close to archaeological sites (off-sites, or near-sites: Mercuri \& al. in press), and from sites located in the Mediterranean countries (Fig. 1).

Following the idea that archaeobotany is a key tool 'for the understanding of the biocultural diversity', the web site hosts the inventory of the archaeological researches including pollen, palynomorphs, seeds/fruits, wood, charcoals and other plant remains analyses, 


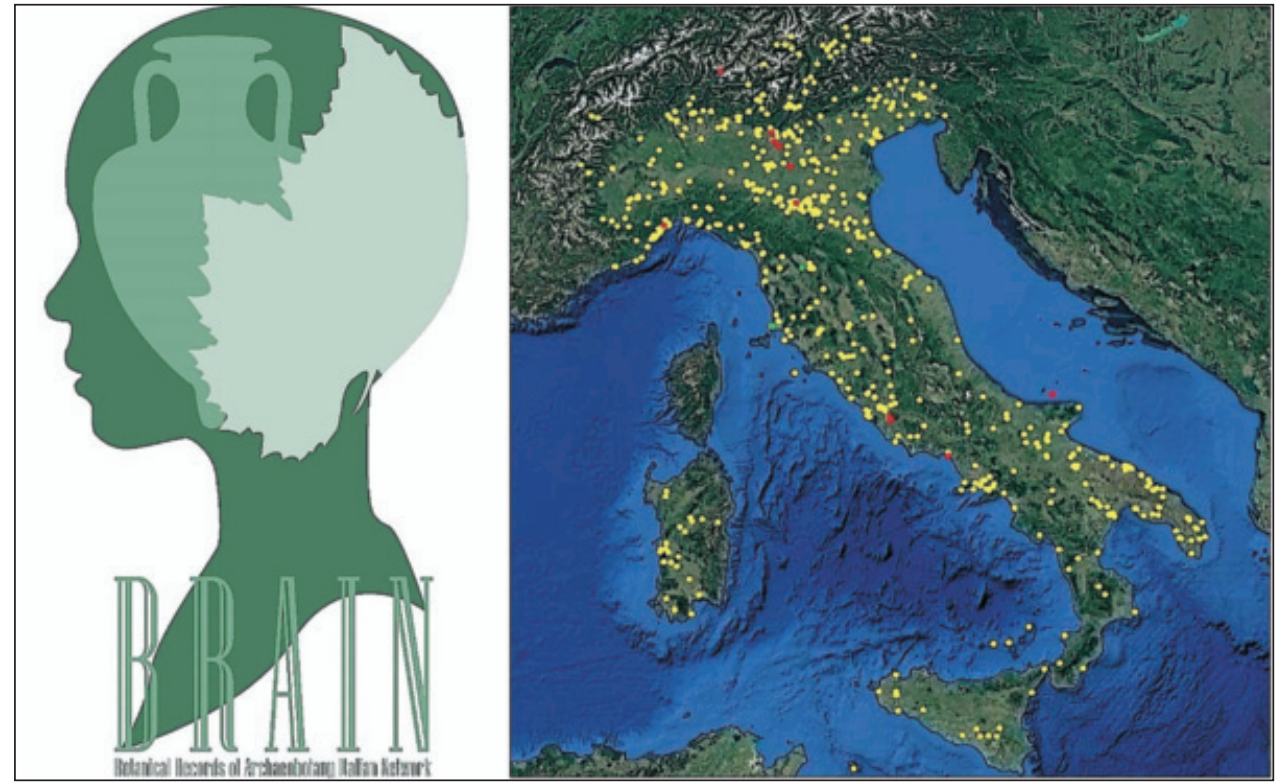

Fig. 1. BRAIN: The Logo (left) puts together humans and plants in one design whose profile recalls a female entity like science, botany and archaeobotany (by Serena Ferretti, Reggio Emilia). Distribution map of the sites in BRAIN (right).

fruitfully used to deepen the history of past vegetation, land cover, land-uses and palaeoethnobotany.

Currently, BRAIN includes $>660$ sites which has been object of archaeobotanical studies, among which 110 in Emilia Romagna, 74 in Apulia, 67 in Lombardy, 64 in Latium, and 39 in Tuscany. The studies have been mainly carried out on Neolithic (119), Bronze age (117), Iron Age (97), Roman (192), and Medieval contexts (119) (Fig. 2).

The website consists of six pages, two of which are especially dedicated to the database including Sites and References. Site position and density are immediately visible in a map while three graphs show updated statistics on the number of sites per area, or Cultural period, or type of plant remain. References may be sorted in alphabetical order, or author names. The first section included only On-sites; recently, three new sections were added: Off-sites, Spot records, and Extra-Italy. New contributors are welcomed.

BRAIN network is a useful instrument for both single and joint researches. The website is also a good way to publicize the impressive work done in the field of archaeobotany in the Italian on-sites (archaeological) or near-sites (human-related environmental sites) and makes the archaeobotanical data available for archaeological researches and studies on conservation and biodiversity on a long-term perspective.

The huge amount of data produced in the last few decades demonstrates that Botany has a key role in improving the knowledge of cultural/archaeological and natural heritage. The increase of the number of papers on archaeobotany (as evinced from BRAIN) shows the versatility and increasing importance of this science in the last years (Fig. 3). 


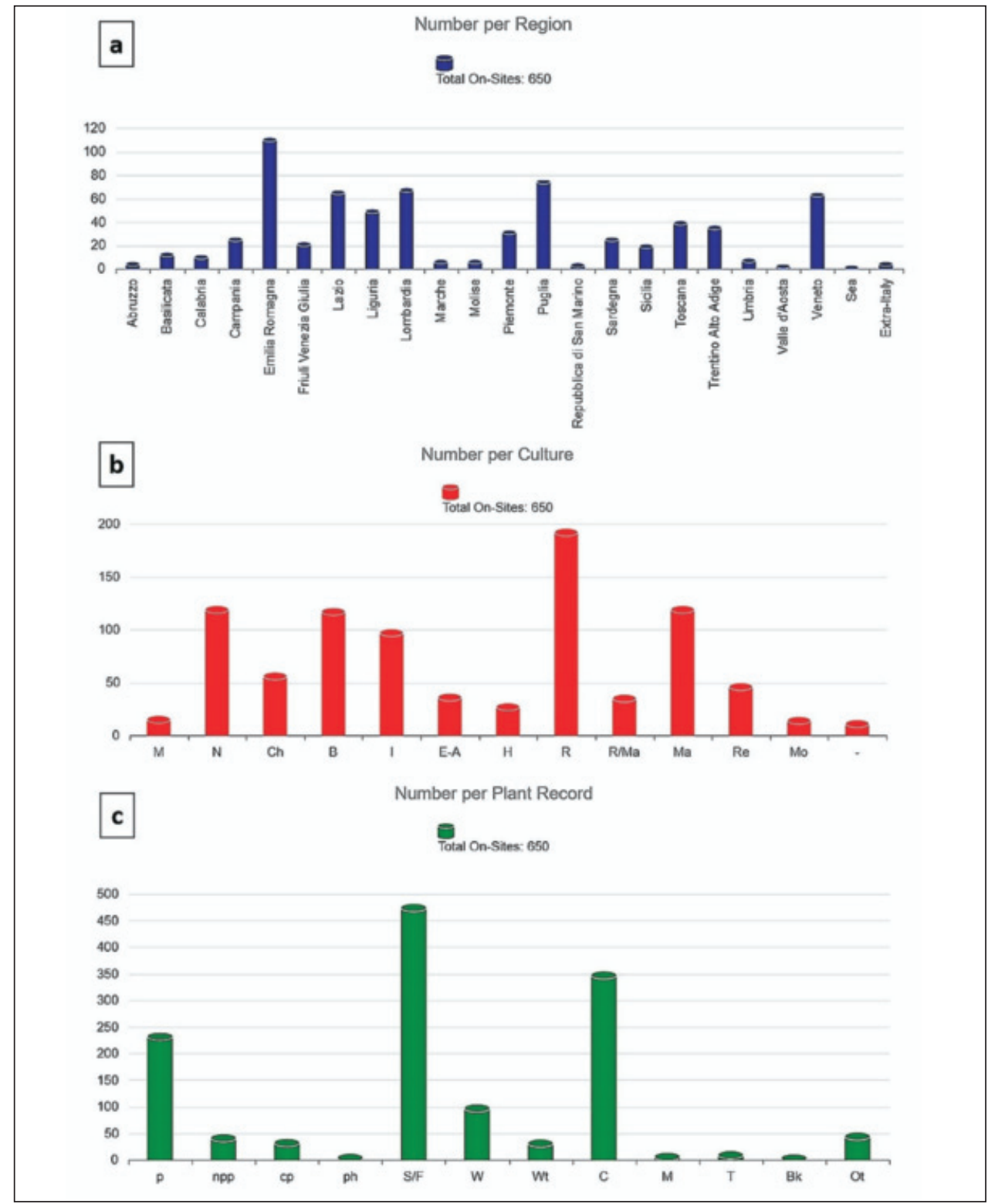

Fig. 2. BRAIN database: real-time statistics on the sites (retrieved October 12, 2018, from https://brainplants.unimore.it/sites.html): a) number of on-sites per region; b) on-sites per culture (M $=$ Mesolithic; $\mathrm{N}=$ Neolithic $\mathrm{Ch}=$ Chalcolithic $\mathrm{B}=$ Bronze age; $\mathrm{I}=$ Iron age; $\mathrm{E}-\mathrm{A}=$ Etruscan-Archaic period; $\mathrm{H}=$ Hellenistic period; $\mathrm{R}=$ Roman age; $\mathrm{Ma}=$ Medieval ages; $\mathrm{Re}=$ Renaissance; $\mathrm{Mo}=$ Modern age); $c)$ on-sites per type of botanical record ( $\mathrm{p}=$ pollen; npp = non-pollen palynomorphs; $\mathrm{cp}=$ micro-charcoal particles; $\mathrm{ph}=$ phytoliths; $\mathrm{S} / \mathrm{F}=$ seed and fruit; $\mathrm{W}=$ wood; $\mathrm{Wt}=$ wood tool; $\mathrm{C}$ = charcoal; $\mathrm{M}=$ mould $; \mathrm{T}=$ textiles; $\mathrm{Bk}=$ basketry; $\mathrm{Ot}=$ adobe, bread or similar food, leaves and microsporophylls, mastic, moss, plant tissues, ropes, straw, wick). 


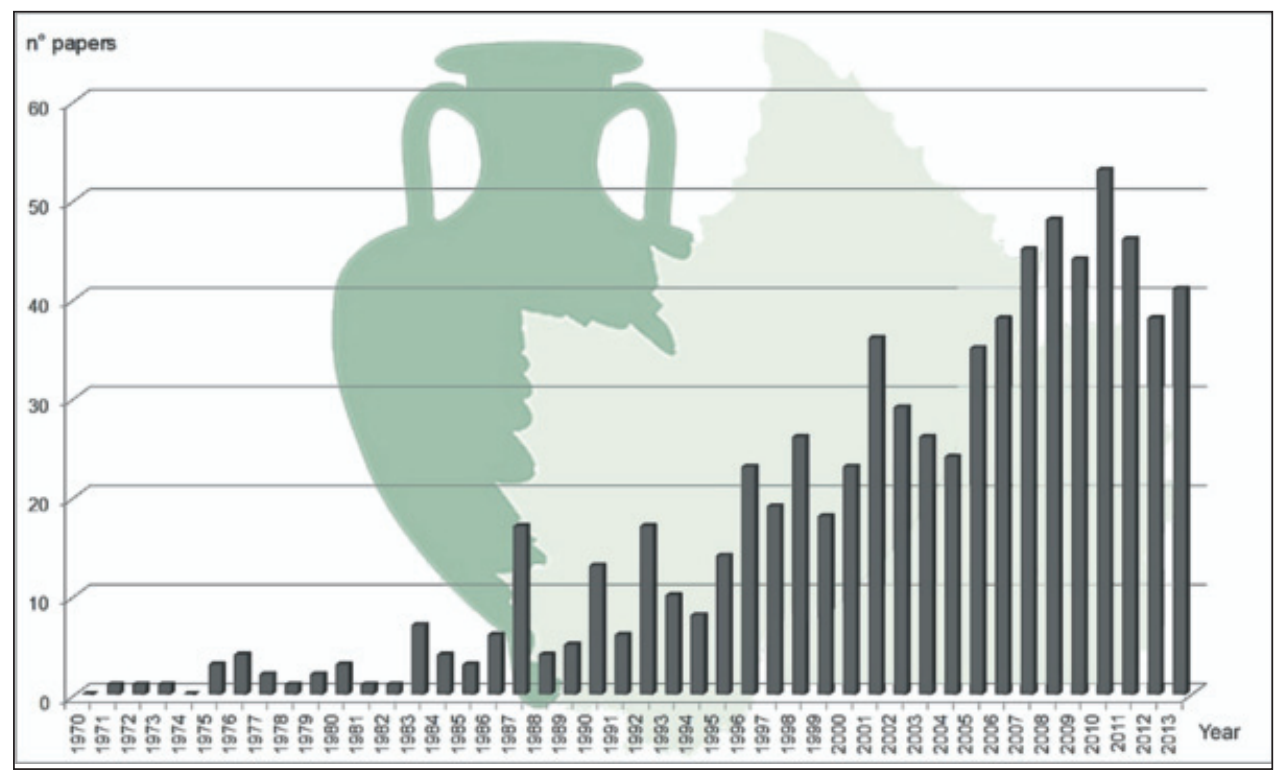

Fig. 3. Number of published archaeobotanical studies according to the list in the BRAIN website. Note the increase in time.

\section{Acknowledgements}

The financial support of BRAIN is given by research funds provided by AM Mercuri. The website and database has been programmed and is updated by Ing. Matteo di Lena and Federico Camerini; the logo was created and drawn by Arch. Serena Ferretti (Reggio Emilia). The authors wish to thank the Organizing Committee of the "Selinunte International Symposium 2018" for the opportunity to present the BRAIN database and network.

MML and AMM planned the contribution and wrote the text, with the help of AF and RR; all Authors read and contributed to the synthesis.

\section{References}

Arobba, D., Caramiello, R., Firpo, M., Mercalli, L., Morandi, L. F. \& Rossi, S. 2018: New evidence on the earliest human presence in the urban area of Genoa (Liguria, Italy): A multi-proxy study of a mid-Holocene deposit at the mouth of the Bisagno river. - Holocene 28(12): 1918-1935. doi: 10.1177/0959683618798107

Bandini Mazzanti, M., Bosi, G., Mercuri, A. M., Accorsi, C. A. \& Guarnieri, C. 2005: Plant use in a city in Northern Italy during the late Mediaeval and Renaissance periods: Results of the archaeobotanical investigation of "The Mirror Pit" (14th-15th century A.D.) in Ferrara. - Veg. Hist. Archaeobot. 14: 442-452. doi: 10.1007/s00334-005-0082-y

Bartolucci, F., Peruzzi, L., Galasso, G., Albano, A., Alessandrini, A., Ardenghi, N. M. G., Astuti, G., Bacchetta, G., Ballelli, S., Banfi, E., Barberis, G., Bernardo, L., Bouvet, D., Bovio, M., Cecchi, L., Di Pietro, R., Domina, G., Fascetti, S., Fenu, G., Festi, F., Foggi, B., Gallo, L., 
Gottschlich, G., Gubellini, L., Iamonico, D., Iberite, M., Jiménez-Mejías, P., Lattanzi, E., Marchetti, D., Martinetto, E., Masin, R. R., Medagli, P., Passalacqua, N. G., Peccenini, S., Pennesi, R., Pierini, B., Poldini, L., Prosser, F., Raimondo, F. M., Roma-Marzio, F., Rosati, L., Santangelo, A., Scoppola, A., Scortegagna, S., Selvaggi, A., Selvi, F., Soldano, A., Stinca, A., Wagensommer, R. P., Wilhalm, T. \& Conti, F. 2018: An updated checklist of the vascular flora native to Italy. - Pl. Biosyst. 152(2): 179-303. doi: 10.1080/11263504.2017.1419996

Benvenuti, M., Bahain, J. J., Capalbo, C., Capretti, C., Ciani, F., D’Amico, C., Esu, D., Giachi, G., Giuliani, C., Gliozzi, E., Lazzeri, S., Macchioni, N., Mariotti Lippi, M., Masini, F., Mazza, P. P. A., Pallecchi, P., Revedin, A., Savorelli, A., Spadi, M., Sozzi, L., Vietti, A., Voltaggio, M. \& Aranguren, B. 2017: Paleoenvironmental context of the early Neanderthals of Poggetti Vecchi for the late Middle Pleistocene of Central Italy. - Quat. Res. 88(2): 327-344. doi: $10.1017 /$ qua.2017.51

Bertini, A., Cirilli, S., Magri, D. \& Stephenson, M. 2015: Editorial: Changing flora and vegetation in Italy through time. - Rev. Palaeobot. Palynol. 218: 1-2. doi: 10.1016/j.revpalbo.2015.04.009

Blasi 2010. La vegetazione d'Italia. - Roma.

Borgongino, M. 2006: Archeobotanica. Reperti vegetali da Pompei e dal Territorio Vesuviano. Roma.

Bosi, G., Mercuri, A. M., Guarnieri, C. \& Bandini Mazzanti, M. 2009: Luxury food and ornamental plants at the 15th century A.D. Renaissance court of the Este family (Ferrara, Northern Italy). - Veg. Hist. Archaeobot. 18: 389-402. doi: 10.1007/s00334-009-0220-z

—, Benatti, A., Rinaldi, R., Dallai, D., Santini, C., Carbognani, M., Tomaselli, M. \& Bandini Mazzanti, M. 2015: The memory of water: Archaeobotanical evidence of wetland plants from Modena (Emilia-Romagna, northern Italy) and palaeoecological remarks. - Pl. Biosyst. 149(1): 144-153. doi: 10.1080/11263504.2014.998310

—, Herchenbach, M., Buldrini, F., Rinaldi, R. \& Mazzanti, M. 2017: On the trail of date-plum (Diospyros lotus L.) in Italy and its first archaeobotanical evidence. - Econ. Bot. 71(2): 133146. doi: 10.1007/s12231-017-9377-z

—, Labate, D., Rinaldi, R., Montecchi M. C., Mazzanti M., Torri, P., Riso, F. M. \& Mercuri, A. M. 2018: A survey of the Late Roman period ( $3^{\text {rd }}-6^{\text {th }}$ century AD): Pollen, NPPs and seeds/fruits for reconstructing environmental and cultural changes after the floods in Northern Italy. - Quat Int. doi: 10.1016/j.quaint.2018.02.002

Bowes, K., Mercuri, A. M., Rattighieri, E., Rinaldi, R., Arnoldus-Huyzendveld, A., Ghisleni, M., Grey, C., Mackinnon, M. \& Vaccaro, E. 2015: Palaeoenvironment and land use of Roman peasant farmhouses in southern Tuscany. - Pl. Biosyst. 149(1): 174-184. doi: 10.1080/11263504.2014.992997

Buonincontri, M., Pecci, A., Di Pasquale, G., Ricci, P. \& Lubritto, C. 2017: Multiproxy approach to the study of Medieval food habits in Tuscany (central Italy). - Archaeol. Anthropol. Sci. 9(4): 653-671. doi: 10.1007/s12520-016-0428-7

Caramiello, R., Fossa, V., Siniscalco, C. \& Arobba, D. 2013: La ricostruzione paleoambientale ad Augusta Bagiennorum in età romana. - Pp. 67-77 in: Preacco, C. (ed.) Augusta bagiennorum. Storia e archeologia di una città augustea. - Torino.

Celant, A. \& Fiorentino, G. 2017: Macroremains of Citrus fruit in Italy. - Pp. 130-138 in: ZechMatterne, V. \& Fiorentino, G. (eds) AGRUMED: Archaeology and history of Citrus fruit in the Mediterranean: Acclimatization, diversifications, uses. - Naples.

-, Magri, D. \& Stasolla, F. R. 2015: Collection of Plant Remains from Archaeological Contexts. Pp. 469-485 in: Yeung, E. C. T., Stasolla, C., Sumner, M. J., Huang, B. Q. (eds), Plant Microtechniques and Protocols. - Cham.

Cremaschi, M., Mercuri, A. M., Torri, P., Florenzano, A., Pizzi, C., Marchesini, M. \& Zerboni, A. 2016: Climate change versus land management in the Po Plain (Northern Italy) during the 
Bronze Age: New insights from the VP/VG sequence of the Terramara Santa Rosa di Poviglio. - Quat. Sci. Rev. 136: 153-172. doi: 10.1016/j.quascirev.2015.08.011

De Marinis, R. C., Rapi, M., Ravazzi, C., Arpenti, E., Deaddis, M. \& Perego, R. 2005: Lavagnone (Desenzano del Garda): new excavations and palaeoecology of a Bronze Age pile dwelling in northern Italy. - Collect. Archaeol. 3: 221-232.

De Pascale, A., Maggi, R., Montanari, C. \& Moreno, D. 2006: Pollen, herds, jasper and copper mines: economic and environmental changes during 4th and 3rd millennia BC in Liguria (NW Italy). Environment. Archaeol. 11: 115-124. doi: 10.1179/174963106x97098

Di Rita, F. \& Melis, D. 2013: The cultural landscape near the ancient city of Tharros (central West Sardinia): vegetation changes and human impact. - J. Archaeol. Sci. 40: 4271-4282. doi: 10.1016/j.jas.2013.06.027

-, Celant, A. \& Magri, D. 2010: Holocene environmental instability in the wetland north of the Tiber delta (Rome, Italy): sea-lake-man interactions. - J Paleolimnol 44: 51-67. doi: 10.1007/s10933009-9385-9

-, Molisso, F. \& Sacchi, M. 2018: Late Holocene environmental dynamics, vegetation history, human impact, and climate change in the ancient Literna Palus (Lago Patria; Campania, Italy). - Rev. Palaeobot. Palynol. 258: 48-61.

Fiorentino, G. \& Parra, I. 2015: "Lost" postglacial littoral environments in SE Italy: Anthracological evidence at Grotta delle Mura. - Rev. Palaeobot. Palynol. 218: 198-203. doi: 10.1016/j.revpalbo. 2018.06 .005

—, Caldara, M., De Santis, V., D’Oronzo, C., Muntoni, I. M., Simone, O., Primavera, M. \& Radina, F. 2013: Climate changes and human-environment interactions in the Apulia region of southeastern Italy during the Neolithic period. - Holocene 23(9): 1297-1316. doi: 10.1177/0959683613486942

Fyfe, R. M., Woodbridge, J. \& Roberts, C. N. 2018: Trajectories of change in Mediterranean Holocene vegetation through classification of pollen data. - Veg. Hist. Archaeobot. 27(2): 351-364. doi: 10.1007/s00334-017-0657-4

Florenzano, A. 2016: Archaeobotanical Analysis. Pp. 159-171 in: Silvestrelli, F. \& Edlund-Berry I. E. M. (eds), The Chora of Metaponto 6: A Greek Settlement at Sant'Angelo Vecchio. - Austin.

Giachi, G., Pallecchi, P., Romualdi, A., Ribechini, E., Lucejko, J. J., Colombini, M. P. \& Mariotti Lippi, M. 2013: Ingredients of a 2,000-y-old medicine revealed by chemical, mineralogical, and botanical investigations. - Proc. Natl. Acad. Sci. U. S. A. 110(4): 1193-1196. doi: 10.1073/pnas. 1216776110

Guido, M. A., Menozzi, B. I., Bellini, C., Placereani, S. \& Montanari, C. 2013: A palynological contribution to the environmental archaeology of a Mediterranean mountain wetland (North West Apennines, Italy). - Holocene 23(11): 1517-1527. doi: 10.1177/0959683613496294

Izdebski, A., Holmgren, K., Weiberg, E., Stocker, S. R., Büntgen, U., Florenzano, A., Gogou, A., Leroy, S. G. A., Luterbacher, J., Martrat, B., Masi, A., Mercuri, A. M., Montagna, P., Sadori, L., Schneider, L., Sicre, M.-L., Triantaphyllou, M. \& Xoplaki, E. 2016: Realising consilience: How better communication between archaeologists, historians and natural scientists can transform the study of past climate change in the Mediterranean. - Quat. Sci. Rev. 136: 5-22. doi: 10.1016/j.quascirev.2015.10.038

Kustatsher, E., Roghi, G., Bertini, A. \& Miola, A. (eds) 2014: La Storia delle piante fossili in Italia. - Bolzano.

Marignani, M., Chiarucci, A., Sadori, L. \& Mercuri, A. M. 2017. Natural and human impact in Mediterranean landscapes: An intriguing puzzle or only a question of time? - Pl. Biosyst. 151(5): 900-905. doi: 10.1080/11263504.2016.1244121

Mariotti Lippi, M., Bandini Mazzanti, M., Bosi, G., Buonincontri, M., Castiglioni, E., Di Pasquale, G., Giardini, M., Marchesini, M., Miola, A., Montanari, C., Rottoli, M., Sadori, L. \& Mercuri, A. M. 2014: Archeobotanica. Pp. 346-391 in: Kustatsher, E., Roghi, G., Bertini, A., Miola, A. (eds), La Storia delle piante fossili in Italia. - Bolzano. 
—, Foggi, B., Aranguren, B., Ronchitelli, A. \& Revedin, A. 2015: Multistep food plant processing at Grotta Paglicci (Southern Italy) around 32,600 cal BP. - Proc. Natl. Acad. Sci. U. S. A. 112(39): 12075-12080. doi: 10.1073/pnas.1505213112

—, Pisaneschi, L., Sarti, L., Lari, M. \& Moggi-Cecchi J., 2017: Insights into the Copper-Bronze Age diet in Central Italy: Plant microremains in dental calculus from Grotta dello Scoglietto (Southern Tuscany, Italy). - J. Archaeol. Sci. 15: 30-39. doi: 10.1016/j.jasrep.2017.07.005

Martinelli, E., Michetti, A. M., Colombaroli, D., Mazzola, E., Motella De Carlo, S., Livio, F., Gilli, A., Ferrario, M. F., Hobig, N., Brunamonte, F., Castelletti, L. \& Tinner, W. 2017: Climatic and anthropogenic forcing of prehistorical vegetation succession and fire dynamics in the Lago di Como area (N-Italy, Insubria). - Quat. Sci. Rev. 161: 45-67. doi: 10.1016/j.quascirev.2017.01.023

Melis, R. T., Di Rita, F., French, C., Marriner, N., Montis, F., Serreli, G., Sulas, F. \& Vacchi, M. 2018 : 8000 years of coastal changes on a western Mediterranean island: A multiproxy approach from the Posada plain of Sardinia. - Mar. Geol. 403: 93-108. doi: 10.1016/j.margeo.2018.05.004

Mercuri, A. M. 2014: Genesis and evolution of the cultural landscape in central Mediterranean: the 'where, when and how' through the palynological approach. - Landscape Ecol. 29(10): 17991810. doi: 10.1007/s10980-014-0093-0

— \& Sadori, L. 2014: Mediterranean culture and climatic change: past patterns and future trends. Pp. 507-527 in: Goffredo, S. \& Dubinsky, Z. (eds), The Mediterranean sea: its history and present challenges. - Dordrecht.

-, Montecchi, M. C., Pellacani, G., Florenzano, A., Rattighieri, E. \& Cardarelli, A. 2015a: Environment, human impact and the role of trees on the Po plain during the Middle and Recent Bronze Age: Pollen evidence from the local influence of the terramare of Baggiovara and Casinalbo. - Rev. Palaeobot. Palynol. 218: 231-249. doi: 10.1016/j.revpalbo.2014.08.009

-, Allevato, E., Arobba, D., Bandini Mazzanti, M., Bosi, G., Caramiello, R., Castiglioni, E., Carra, M. L., Celant, A., Costantini, L., Di Pasquale, G., Fiorentino, G., Florenzano, A., Guido, M., Marchesini, M., Mariotti Lippi, M., Marvelli, S., Miola, A., Montanari, C., Nisbet, R., PeñaChocarro, L., Perego, R., Ravazzi, C., Rottoli, M., Sadori, L., Ucchesu, M. \& Rinaldi, R. 2015b: Pollen and plant remains from Holocene archaeological sites: a dataset for the understanding of the bio-cultural diversity of the Italian landscape. - Rev. Palaeobot. Palynol. 218: 250-266. doi: 10.1016/j.revpalbo.2014.05.010

Mercuri, A. M., Florenzano, A., Burjachs, F., Giardini, M., Kouli, K., Masi, A., Picornell-Gelabert, L., Revelles, J., Sadori, L., Servera-Vives, G., Torri, P. \& Fyfe, R. in press: From influence to impact: the multifunctional land-use in Mediterranean prehistory emerging from palynology of archaeological sites (8.0-2.8 ka BP). Holocene.

Molinari, C. \& Montanari, C. 2016: Interdisciplinary approach for reconstructing an alder based historical agricultural practice in Eastern Ligurian Apennines (NW Italy). - Environment. Archaeol. 21(1): 31-44. doi: 10.1179/1749631414Y.0000000056

Montecchi, M. C. \& Mercuri, A. M. 2018: When palynology meets classical archaeology: the Roman and Medieval landscapes at the Villa del Casale di Piazza Armerina, UNESCO site in Sicily. - Archaeol. Anthropol. Sci. doi: 10.1007/s12520-016-0442-9

Moreno, D. \& Montanari, C. 2008: Màs allà de la percepción: hacia una ecología histórica del paisaje rural en Italia. - Cuad. Geogr. Univ. Granada 43: 29-49.

Moser, D., Nelle, O. \& Di Pasquale, G. 2018: Timber economy in the Roman Age: charcoal data from the key site of Herculaneum (Naples, Italy). - Archaeol Anthropol. Sci. 10(4): 905-921. doi: 10.1007/s12520-016-0406-0

Perego, R., Badino, F., Deaddis, M., Ravazzi, C., Vallè, F. \& Zanon, M. 2011: L'origine del paesaggio agricolo pastorale in nord Italia: espansione di Orlaya grandiflora $(\mathrm{L}$.) Hoffm. nella civiltà palafitticola. - Not. Archeol. Bergomensis 19: 161-173. 
Orrù, M,, Grillo, O., Lovicu, G., Venora, G. \& Bacchetta, G. 2013: Morphological characterisation of Vitis vinifera L. seeds by image analysis and comparison with archaeological remains. Veg. Hist. Archaeobot. 22: 231-242. doi: 10.1007/s00334-012-0362-2

Pini, R., Castellano, L., Perego, R., Ravazzi, C., Chiesa, S. \& De Amicis, M. 2016a: Nuovi dati sulla storia ambientale del centro abitato di Bergamo Alta tra la fase arcaica dell'età del Bronzo e il Medioevo. Stratigrafia, paleoecologia e archeobotanica dei depositi del Palazzo del Podestà (Piazza Vecchia). - Ateneo Sci. Lett. Arti Bergamo 79: 349-371.

_, _, _, — \& Rizzi, A. 2016b: Un insediamento perilacustre del Tardo Neolitico - Età del Rame a Fimon Le Fratte. Successione sedimentaria, stratigrafia pollinica e macroresti vegetali. - Pp. 169194 in: Bianchin Citton, E. (ed.), Nuove ricerche nelle Valli di Fimon. L'insediamento del tardo Neolitico de Le Fratte di Arcugnano. - Vicenza.

Piovesan, G., Mercuri, A. M. \& Mensing, S. A. 2018. The potential of paleoecology for functional forest restoration planning: lessons from the Late Holocene Italian pollen records. - Pl. Biosyst. 152(3): 508-514. doi: 10.1080/11263504.2018.1435582

Primavera, M., Heiss, A. G., Valamoti, M. S., Quarta, G., Masieri, M. \& Fiorentino, G. 2018: Inside sacrificial cakes: plant components and production processes of food offerings at the Demeter and Persephone sanctuary of Monte Papalucio (Oria, southern Italy). - Archaeol. Anthropol. Sci. doi: 10.1007/s12520-018-0605-y

Revedin, A., Aranguren, B., Becattini, R., Longo, L., Marconi, E., Mariotti Lippi, M., Skakun, N., Sinitsyn, A. A., Spiridonova, E. A. \& Svoboda, J. 2010: Thirty thousand-year-old evidence of plant food processing. - Proc. Natl. Acad. Sci. U. S. A. 107(44): 18815-18819. doi: 1 0.1073/pnas.1006993107

Rottoli, M. 2014: Reflections on Early Medieval resources in northern Italy: The archaeobotanical and archaeozoological data. - Quat. Int. 346: 20-27. doi: 10.1016/j.quaint.2014.01.014

Sabato, D., Masi, A., Ucchesu, M., Peña-Chocarro, L., Usai, A., Giachi, G., Capretti, C. \& Bacchetta, G. 2015. Archaeobotanical analysis of a Bronze Age well from Sardinia: a wealth of knowledge. - Pl. Biosyst. 149(1): 205-215. doi: 10.1080/11263504.2014.998313

Sabato, D., Esteras, C., Grillo, O., Peña-Chocarro, L., Leida, C., Ucchesu, M., Usai, A., Bacchetta, G. \& Picó, B. 2017. Molecular and morphological characterisation of the oldest Cucumis melo L. seeds found in the Western Mediterranean Basin. - Archaeol. Anthropol. Sci. doi: 10.1007/s12520-017-0560-z

Sadori, L. 2018: The Lateglacial and Holocene vegetation and climate history of Lago di Mezzano (central Italy). - Quat. Sci. Rev. (accepted).

-, Mercuri, A. M. \& Mariotti Lippi, M. 2010: Reconstructing past cultural landscape and human impact using pollen and plant macroremains. - Pl. Biosyst. 144(4): 940-951. doi: 10.1080/11263504.2010.491982

—, Bertini, A., Combourieu-Nebout, N., Kouli, K., Mariotti Lippi, M., Roberts, N. \& Mercuri, A. M. 2013: Palynology and Mediterranean vegetation history. - Fl. Medit. 23: 141-156. doi: $10.7320 /$ FlMedit23.141

Sadori, L., Allevato, E., Bellini, C., Bertacchi, A., Boetto, G., Dio Paquale, G., Giachi, G., Giardini, M., Masi, A., Pepe, C., Russo Ermolli, E. \& Mariotti Lippi, M. 2015: Archaeobotany in Italian ancient Roman harbours. - Rev. Palaeobot. Palynol. 218: 217-230. doi: 10.1016/j.revpalbo.2014.02.004

Stagno, A. M., Parola, C. \& Montanari, C. 2014: Archaeology and Archaeobotany for the history of the Costa dei Ghiffi slopes. - In: Stagno, A. M. (ed.), Montagne Incise - Pietre Incise. Archeologia delle risorse della montagna mediterranea. - APM 17: 417-432. doi: 10.1400/228604

Toffolo, L., Addis, A., Martin, S., Nimis, P., Rottoli, M. \& Godard, G. 2018: The Misérègne slag deposit (Valle d'Aosta, Western Alps, Italy): Insights into (pre)Roman copper metallurgy. - J. Archaeol. Sci. 19: 248-260. doi: 10.1016/j.jasrep.2018.02.030 
Ucchesu, M., Orrù, M., Grillo, O., Venora, G., Paglietti, G., Ardu, A. \& Bacchetta, G. 2016: Predictive Method for Correct Identification of Archaeological Charred Grape Seeds: Support for Advances in Knowledge of Grape Domestication Process. - PloSONE 11(2): e0149814. doi: 10.1371/journal.pone.0149814

—, Sarigu, M., Del Vais, C., Sanna, I., D’Hallewin, G., Grillo, O. \& Bacchetta G. 2017: First finds of Prunus domestica L. in Italy from the Phoenician and Punic periods (6th-2nd centuries BC). - Veg Hist Archaeobot 26: 539-549. doi: 10.1007/s00334-017-0622-2

Vittori Antisari, L., Bianchini, G., Cremonini, S., Di Giuseppe, D., Falsone, G., Marchesini, M., Marvelli, S. \& Vianello, G. 2016: Multidisciplinary study of a Lateglacial-Holocene sedimentary sequence near Bologna (Italy): insights on natural and anthropogenic impacts on the landscape dynamics. - J. Soils Sediments 16: 645-662. doi: 10.1007/s11368-015-1266-4

Addresses of the authors:

Marta Mariotti Lippi ${ }^{1}$, Assunta Florenzano ${ }^{2}$, Rossella Rinaldi ${ }^{2}$, Emilia Allevato ${ }^{3}$, Daniele Arobba ${ }^{4}$, Gianluigi Bacchetta ${ }^{5}$, Marie-Claude $\mathrm{Bal}^{6}$, Marta Bandini Mazzanti $^{2}$, Alessandra Benatti ${ }^{2}$, Jaromir Beneš ${ }^{7}$, Giovanna Bosi², Mauro Buonincontri $^{3}$, Rosanna Caramiello ${ }^{8}$, Lanfredo Castelletti ${ }^{9}$, Elisabetta Castiglioni ${ }^{10}$, Alessandra Celant ${ }^{11}$, Eleonora Clò ${ }^{2}$, Lorenzo Costantini ${ }^{12}$, Gaetano Di Pasquale ${ }^{3}$, Federico Di Rita ${ }^{11}$, Girolamo Fiorentino ${ }^{13}$, Giulia Furlanetto ${ }^{14}$, Marco Giardini ${ }^{11}$, Oscar Grillo ${ }^{5}$, Mariangela Guido ${ }^{15}$, Michael Herchenbach ${ }^{16}$, Donatella Magri ${ }^{11}$, Marco Marchesini ${ }^{17}$, Michele Maritan ${ }^{18}$, Silvia Marvelli ${ }^{17}$, Alessia Masi ${ }^{11}$, Antonella Miola $^{18}$, Carlo Montanari ${ }^{15}$, Maria Chiara Montecchi ${ }^{2}$, Sila Motella ${ }^{9}$, Renato Nisbet $^{19}$, Martino Orrù ${ }^{5}$, Leonor Peña-Chocarro ${ }^{20}$, Caterina Pepe ${ }^{11}$, Renata Perego ${ }^{14}$, Eleonora Rattighieri ${ }^{2}$, Cesare Ravazzi ${ }^{14}$, Mauro Rottoli ${ }^{10}$, Erica Rowan ${ }^{21}$, Diego Sabato $^{5}$, Laura Sadori ${ }^{11}$, Marco Sarigu ${ }^{5}$, Paola Torri ${ }^{2}$, Mariano Ucchesu ${ }^{5} \&$ Anna Maria Mercuri ${ }^{2}$,

${ }^{1}$ Dip. Biologia, Università di Firenze, Via la Pira 4, 50100 Firenze, Italy. Email: mariotti@unifi.it

${ }^{2}$ LPP, Dip. Scienze Vita, Università di Modena e Reggio Emilia, Viale Caduti in Guerra 127, 41121 Modena, Italy. Email: assunta.florenzano@unimore.it; rossella.rinaldi@unimore.it; marta.mazzanti@unimore.it; aleben87@yahoo.it; giovanna.bosi@unimore.it; eleonora.clo@unimore.it; mc.montecchi@gmail.com; ratti68@hotmail.com; paola.torri@unimore.it; annamaria.mercuri@unimore.it

${ }^{3}$ Dip. Agraria, Università di Napoli Federico II, Via Università 100, 80055 Portici (NA), Italy. Email: eallevat@unina.it; mauropaolo.buonincontri@unina.it; gaetano.dipasquale@unina.it

${ }^{4}$ Museo Archeologico del Finale, Ist. Int.le Studi Liguri, Chiostri di Santa Caterina, 17024 Finale Ligure Borgo (SV), Italy. Email: arobba@museoarcheofinale.it

${ }^{5}$ Banca del Germoplasma della Sardegna (BG-SAR), Hortus Botanicus Karalitanus (HBK), Università degli Studi di Cagliari, viale Sant'Ignazio da Laconi 9-11, 09123 Cagliari, Italy. Email: bacchet@unica.it; oscar.grillo.mail@gmail.com; martino.orru@gmail.com; diegosabato@libero.it; msarigu@unica.it; marianoucchesu@gmail.com

${ }^{6}$ GEOALB-UMR 6042, Department of Geography, Université de Limoges, Limoges, France. Email: marie-claude.bal@unilim.fr

${ }^{7}$ University of South Bohemia, Faculty of Science, LAPE; Faculty of Philosophy, Institute of Archaeology, České Budějovice, Czech Republic. Email: benes.jaromir@gmail.com 
${ }^{8}$ DBios, Università di Torino, Viale P.A. Mattioli 25, 10125 Torino, Italy. Email: rosanna.caramiello@unito.it

${ }^{9}$ Laboratorio di Archeobiologia dei Musei Civici di Como, piazza Medaglie d'Oro 1, 22100 Como, Italy. Email: lanfredo.castelletti@gmail.com; sila.motella@uninsubria.it

${ }^{10}$ AR.CO. Società Cooperativa di Ricerche Archeobiologiche, piazza Medaglie d'Oro 1, 22100 Como, Italy. Email: castiglioni.eli@alice.it; archeobotanica@alice.it ${ }^{11}$ Dip. Biologia Ambientale, Sapienza Università di Roma, Piazzale Aldo Moro 5, 00185 Roma, Italy. Email: alessandra.celant@uniroma1.it; federico.dirita@uniroma1.it; donatella.magri@uniroma1.it; alessia.masi@uniroma1.it; caterina.pepe@uniroma1.it; laura.sadori@uniroma1.it

${ }^{12}$ Centro di Bioarcheologia e Microscopia Elettronica, Museo Nazionale d'Arte Orientale "Giuseppe Tucci", Via Merulana 248, 00185 Roma, Italy. Email: 1.costantini@mclink.it

${ }^{13}$ Laboratorio di Archeobotanica e Paleoecologia, Dip Beni Culturali, Università del Salento, Via D. Birago 64, 73100 Lecce, Italy. Email: girolamo.fiorentino@unisalento.it ${ }^{14}$ CNR I.D.P.A. Vegetation, Climate and Human Stratigraphy Research Group, c/o DISAT, Univ. Milano Bicocca, Piazza della Scienza 1, 20126 Milano, Italy. Email: giulia.furlanetto@idpa.cnr.it; renaperego1@gmail.com; cesare.ravazzi@idpa.cnr.it ${ }^{15}$ Laboratorio di Palinologia e Archeobotanica, DIP.TE.RIS., Università di Genova, Corso Dogali 1 M, 16136 Genova, Italy. Email: maria.angela.guido@unige.it; carlo.montanari@unige.it

${ }^{16}$ Institut für Geschichtswissenchaft, University of Bonn, Germany. Email: mherchenbach@uni-bonn.de

${ }^{17}$ Laboratorio di Palinologia e Archeobotanica, C.A.A. Giorgio Nicoli, Via Marzocchi 17 c/o ARE "La Bora”, 40017 San Giovanni in Persiceto (BO), Italy. Email: mmarchesini@caa.it; smarvelli@caa.it

${ }^{18}$ Dip Biologia, Università di Padova, Via Ugo Bassi 58/B, 35121 Padova, Italy. Email: michele.maritan@unipd.it; antonella.miola@unipd.it

${ }^{19}$ Dip Studi sull'Asia e sull'Africa Mediterranea, Università Ca' Foscari, San Polo 2035, Calle del Magazen, 30125 Venezia, Italy. Email: renato.nisbet@unive.it

${ }^{20} \mathrm{CSIC}$, GI Arqueobilogía, Instituto de Historia, C/Albasanz 26-28, 28037 Madrid, Spain. Email: leonor.chocarro@csic.es

${ }^{21}$ Royal Holloway, University of London, Egham Hill, Egham TW20 0EX, United Kingdom. Email: erica.rowan@rhul.ac.uk 